\title{
Neuroanatomical structures manufacture: an alternative in the practical teaching of neuroanatomy
}

\author{
FALCÃO, J. G. B. ${ }^{1}$, SANDES, A. A. G. ${ }^{1}$, RODRIGUES, B. R. ${ }^{1}$, \\ NASCIMENTO, I. Y. M. ${ }^{1}$, SCHWINGEL, P. A. ${ }^{2,3}$ and SILVA JÚNIOR, E. X. ${ }^{4,5 *}$
}

\author{
${ }^{1}$ Human Anatomy Teaching and Research Laboratory - LABEPAH, Universidade de Pernambuco - UPE, \\ BR 203, Km 02, s/n, CEP 56328-903, Petrolina, PE, Brazil \\ ${ }^{2}$ Science Education Program, Universidade Federal do Rio Grande do Sul - UFRGS, \\ Rua Ramiro Barcelos, 2600, Prédio Anexo, CEP 90035-003, Porto Alegre, RS, Brazil \\ ${ }^{3}$ Research Laboratory for Human Performance, Departament of Nutrition, Universidade de Pernambuco - UPE, \\ BR 203, Km 02, s/n, CEP 56328-903, Petrolina, PE, Brazil \\ ${ }^{4}$ Universidade Federal do Rio Grande do Sul - UFRGS, Rua Ramiro Barcelos, 2600, \\ Prédio Anexo, CEP 90035-003, Porto Alegre, RS, Brazil \\ ${ }^{5}$ Human Anatomy Teaching and Research Laboratory - LABEPAH, Departament of Physiotherapy, \\ Universidade de Pernambuco - UPE, BR 203, Km 02, s/n, CEP 56328-903, Petrolina, PE, Brazil \\ *E-mail: edivaldo.junior@upe.br
}

\begin{abstract}
Introduction: The neuroanatomy discipline is seen by students as one of the most complex and difficult of the basic cycle in health courses. This is taught with lectures and practical classes, where in the last one, the use is made of corpse parts. However, the use of this type of material has been decreasing making it professors and monitors search for new alternatives. One of these alternatives is the manufacture and the use of neuroanatomical models that assist and facilitate the understanding of practical teaching and learning. The study aims to manufacture neuroanatomical models alternative for the practical Neuroanatomy classes. Materials and Methods: The study is an action research, exploratory, descriptive, where were made neuroanatomical models in the Human Anatomy Laboratory at the University of Pernambuco, Petrolina, with cheap materials in order to improve learning in practical teaching. The confections of these models were made with polystyrene, biscuit dough, string, colored acrylic paint, ink colored oil, rubberized, cardboard and plaster bandages. Results: Were made ten neuroanatomical parts that corresponding to the spinal cord, reticular formation and the dermatomes of the limbs. Conclusion: It was observed that the manufacturing of these models is necessary for conducting practical classes being possible elaborate them with quality at low cost, being an alternative in front of real difficulties in obtaining corpse parts and being a strong tool in the teaching and learning of the Neuroanatomy discipline. But regardless of the alternatives utilized, the confection of models will never replace the use of corpse parts.
\end{abstract}

Keywords: anatomy teaching, human anatomy, modeling and simulation, neuroanatomy, education.

\section{Introduction}

The study of anatomy has always exercised a real fascination for man. It is a science that studies the constitution and the development of organized beings, including the nervous system, which is studied in Neuroanatomy, a branch of Human Anatomy (FATTINI and DANGELO, 2011). This course forms part of the basic health courses cycle (AVERSI- FERREIRA, MONTEIRO, MAIA et al., 2008).

The integration of the animal with the environment is dependent on the nervous system (NS) which controls and coordinates the functions of all body systems, and receives stimuli, interprets them and makes an answer (MACHADO, 2014). The importance of NS has particular relevance, which has made most medical schools, works out a discipline part, the Neuroanatomy (FATTINI and DANGELO, 2011).

For anatomical study, it is necessary to use several alternatives, ranging from the corpse, cadaveric parts, synthetic models, software, Atlas, imaging, social networking, making anatomical models with inexpensive materials and screenplays for practical classes (NOBESCHI, 2010; JAFFAR, 2012; JAFFAR, 2013; SILVA JÚNIOR, MORAES, DIAS et al., 2014a; SILVA JÚNIOR, NASCIMENTO, DIAS et al., 2014b). The acquisition of bodies, unclaimed, for the study of anatomy, has reduced. Law 8501 of November 30th, 1992 designs bodies with natural death for the study and research primarily to institutions with a degree in medicine, leaving out other health area courses, compromising, in part, the teaching and learning human anatomy (BRASIL, 1992; MELO and PINHEIRO, 2010). According Fornazieiro, Gordan, Carvalho et al. (2010), the combination of lectures with practical classes contribute to the formation of the student's knowledge, thus corpse parts and synthetic anatomical models are so important in the construction of anatomical knowledge.

Besides the lack of corpses that contribute to the teaching of anatomy, some neuroanatomical corpse structures are difficult to obtain due to its size, location, access and the difficulty at the time of dissection. Thus, the use of alternative anatomical 
pieces to its study, it is necessary (AVERSI- FERREIRA, MONTEIRO, MAIA et al., 2008). One of these alternatives is the manufacturing of anatomical models to the teaching and learning of human anatomy, in particular Neuroanatomy (SILVA JÚNIOR, NASCIMENTO, DIAS et al., 2014b). In addition to fabricate optional materials for the development of practical classes, the use of internet is being a efficient tool used by most students such as videos on Youtube channel and the social network Facebook (COSTA and LINS, 2012; JAFFAR, 2012; JAFFAR, 2013).

Change the shape of teaching classes cause motivation and create new ways to develop the knowledge is important, allowing an improved understanding of the subjects and making them enjoyable and stimulating (CABELLO, 2009).

Modeling to help to understand the details of NS morphology has been used due to the decrease of corpses in anatomy laboratories (CAMPOS, BORTOLOTO and FELICIO, 2002). It is important to socialize professors and students, and accept the knowledge brought by all in order to enhance learning and teaching methodologies (CABELLO, 2009). The manufacturing of materials through the discipline of monitors assists and contributes to the understanding of the student, as well as facilitate the identification of structures that are difficult to access in corpse.

Thus, the present work had as objective to manufacture alternative human neuroanatomical models for the practical classes of discipline Neuroanatomy at the University of Pernambuco, Petrolina.

\section{Methodology}

The study is an action research, exploratory and descriptive, which was developed in the Human Anatomy Laboratory at the University of Pernambuco, Petrolina, in the period from March to December 2014. The preparation of the models was performed by student-monitors, selected for the monitoring program in Anatomy, in order to meet and to minimize the deficits found in the laboratory.

For models manufactured of low cost materials have been used, such as polystyrene, plaster bandage, string, several ink colors to tissue and oil, biscuit dough, different types of glue, paper EVA (Ethyl Vinyl Acetate) and PVC (Polyvinyl Chloride) pipe; to improve the identification of macroscopic and microscopic structures of the NS, and that usually are not preserved in corpse dissection.

\section{Results and Discussion}

Were confectioned from the cheap material models representing the NS structures, which are microscopic, or macroscopic representative only. Among the elaborate artistic models are: spinal cord (SC), cross sections of the SC, reticular formation and cutaneous innervation of the upper and lower limbs (dermatomes).

According Machado (2014), the SC is a simple NS organ and that communicates the uppermost regions of the central nervous system with the lower and distal leading sensitive information, bringing motor and reflex responses. Therefore, for a longitudinal and external elaboration, anterior and posterior faces, a polystyrene mold coated biscuit dough had been able to ensure a more rigid was necessary. Added to the mold utilized acrylic and oil inks to the macroscopic details and string ties representing the 31 pairs of spinal nerves along with the cauda equina. In the development of these structures, it was noticed that the oil ink is easy to handle, but its drying time was long for the polystyrene and the biscuit, compromising the agility and the manufacturing of the model. Thus, the oil ink was replaced by acrylic ink showed a better response to be used (Figures 1A, B).

In transverse sections of the split segment $\mathrm{SC}$ is viewed in more details, that is, white matter (WM) in the periphery and gray matter (GM) in the center. The WM consists of the extensions of neurons, like axons, able to capture the information; GM composition is by cellular bodies showing a shape of "H" or butterfly (Machado, 2014). This "H" has spinal anterior horn, posterior and lateral. From these horns depart extensions of neurons that will make up the sensory nerves (posterior view of the SC) and motors (anterior view of the SC) (MARTINEZ, ALLODI, UZIEL et al., 2014).

For cross sections was used polystyrene as a basis, and acrilex inks for the designs of the " $\mathrm{H}$ " spinal cord and tracts. All the preparations have been based on the images by Sobotta, Putz and Pabst (2013), so that, there were maximum trustworthiness models.

It was chosen to exemplify the nerve conduction tracts the cervical region wherein they have been painted with different colors for ease of understanding, since these structures are merely physiological conditions (Figure 2).

The models of the reticular formation were prepared using polystyrene, acrilex inks and brush (Figures 3 ). The crosslink formation is an aggregate of neurons of different sizes and types, located inside the brainstem and upper portion of the SC and related with the activation of the cerebral cortex, sleep and wakefulness, etc. (Martin, 2013).

The production of these models has the main factor showing the location of the reticular formation in NS, as well as evidence of practical way something that is not visible, in which its content is totally physiological.

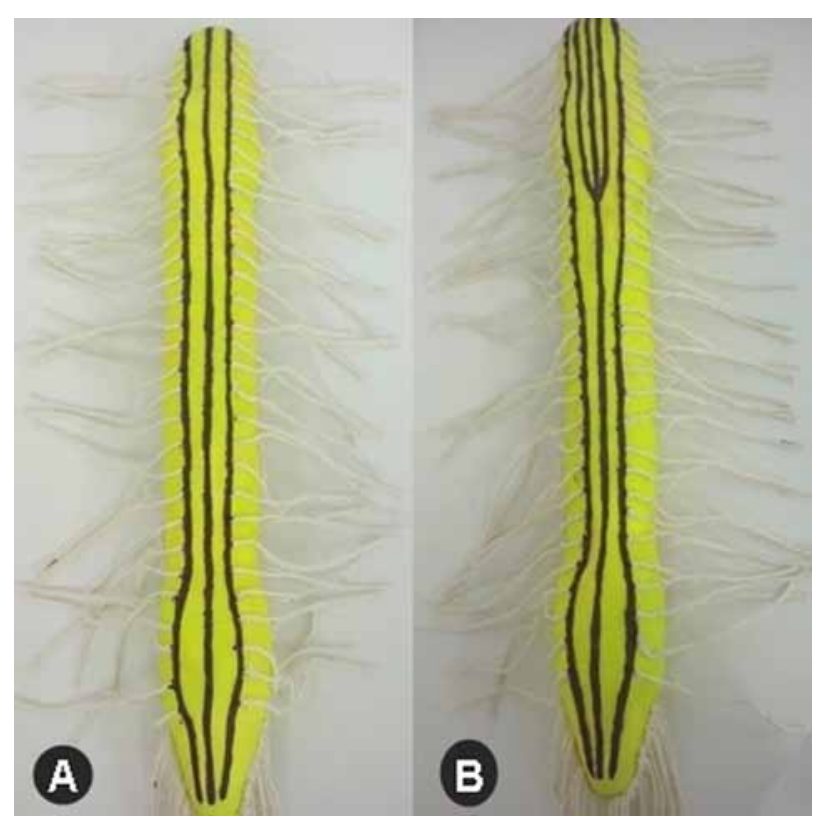

Figure 1. Spinal Cord. (A): anterior view; (B): posterior view. Source: elaborated by the authors. 

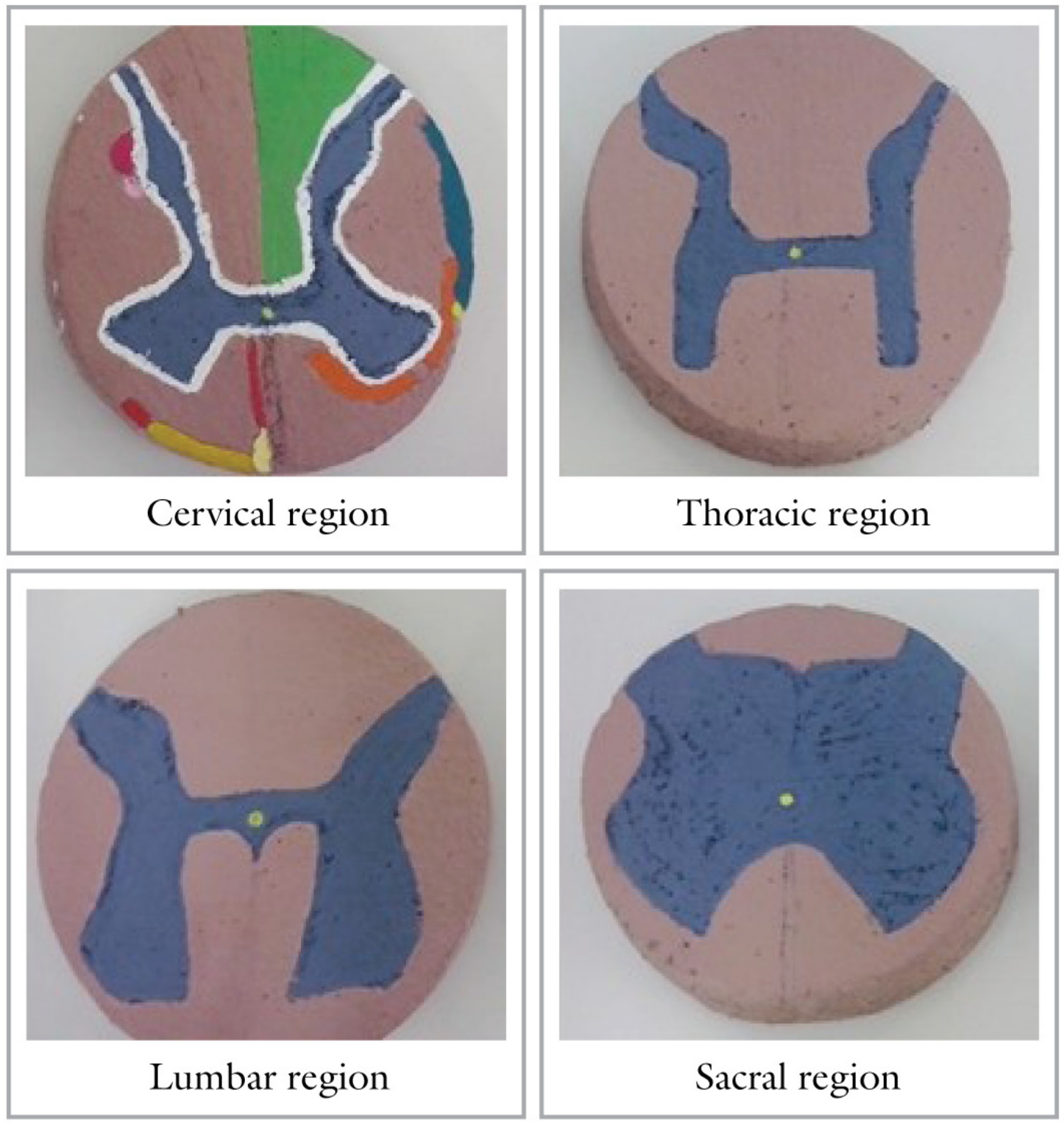

Figure 2. Transversal section of spinal cord. Source: elaborated by the authors.

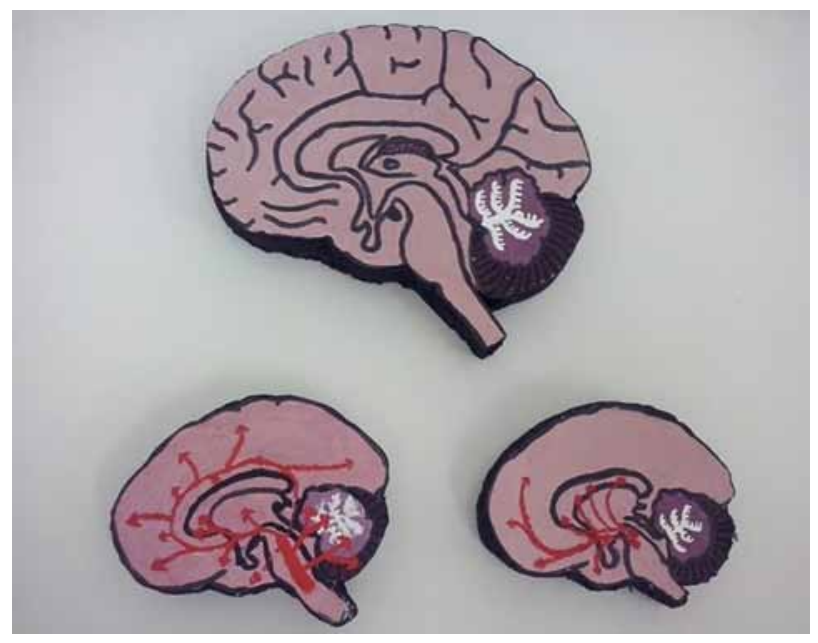

Figure 3. Reticular formation. Source: elaborated by the authors.
Dermatomes represent the cutaneous innervation of the human body (Gray and Goss, 2012). They were made the upper and lower limbs dermatomes. The models were made with plaster bandages then was used acrilex and oil inks, of different colors to highlight and to differentiate the regions innervated by the Peripheral Nervous System (PNS). These regions make up the areas of action of the brachial and lumbosacral plexi. The plexi, according Machado (2014), are sets of nerves originating SC and that supply members, which originate the cervical and lumbar intumescences to form the plexi mentioned above, respectively.

The use of Gray and Goss (2012) book and the atlas of human anatomy Gilroy (2007) have been essentials for the representation of reliably dermatomes with the literature. The manufacture of the models can provide a better student interaction with the material, since the materials allow a better understanding and identification for students of the regions in which they operate the PNS terminal branches in the 
upper and lower limbs, interactively and playful for teaching Neuroanatomy (Figures 4 and 5 ).

According Souza Júnior, Carvalho, Salgado et al. (2010), the use of alternative methodologies for the teaching of human anatomy is useful, facilitates the learning of subjects, addresses the content more accurately and increases the amount of information, improving the understanding and the quality of teaching and learning of the students. Studies, such as Collipal and Silva (2011), Lima e Silva, Machado and Biazussi (2012) and Pereira, Cavalcanti, Portela et al. (2013) evidenced the importance of using artistic models for the teaching of

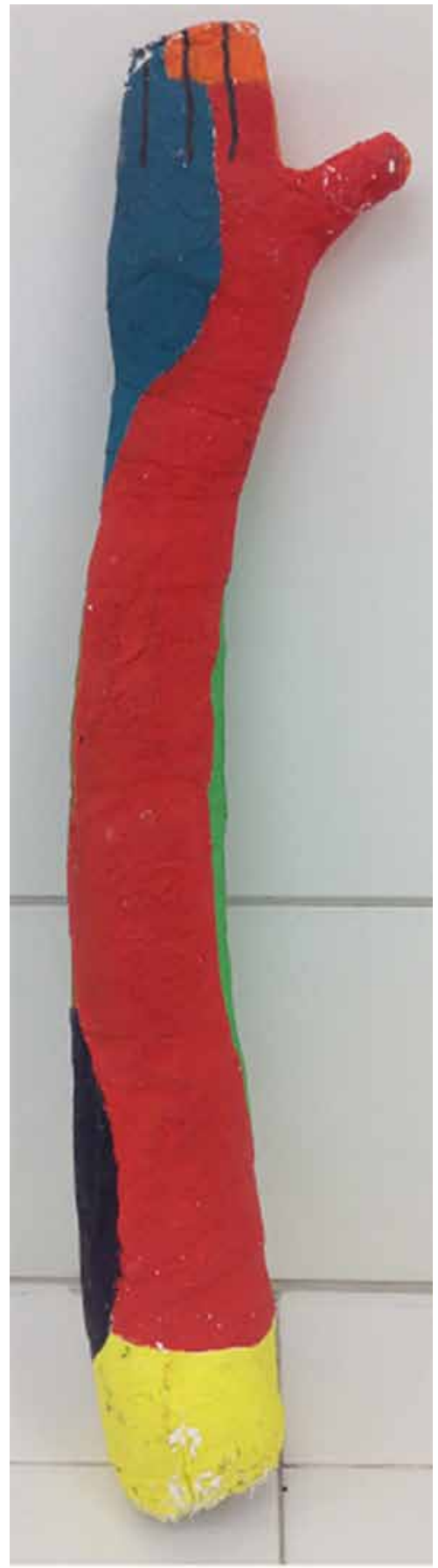

Figure 4. Upper limb dermatome. Source: elaborated by the authors. anatomy, taking into account the lack of corpse parts where made models meet their educational objectives instrument.

López, Sandoval, Giménez et al. (2011) observed the evolution of students in using the anatomical models, according to the learning style and how it affected in their skills at university, obtaining as a result an appreciation of these educational alternatives for students. With this, the skills and learning of anatomy has undergone significant growth.

According to the studies reported above, one can see the importance in the manufacture of neuroanatomic models, as an alternative form in the absence of corpse parts, enabling students to an understanding of the content to be worked in the practical classes, which could be observed with the applicability materials manufactured in this paper when presented to the students in practical classes and visits schools and colleges of the Petrolina city area.

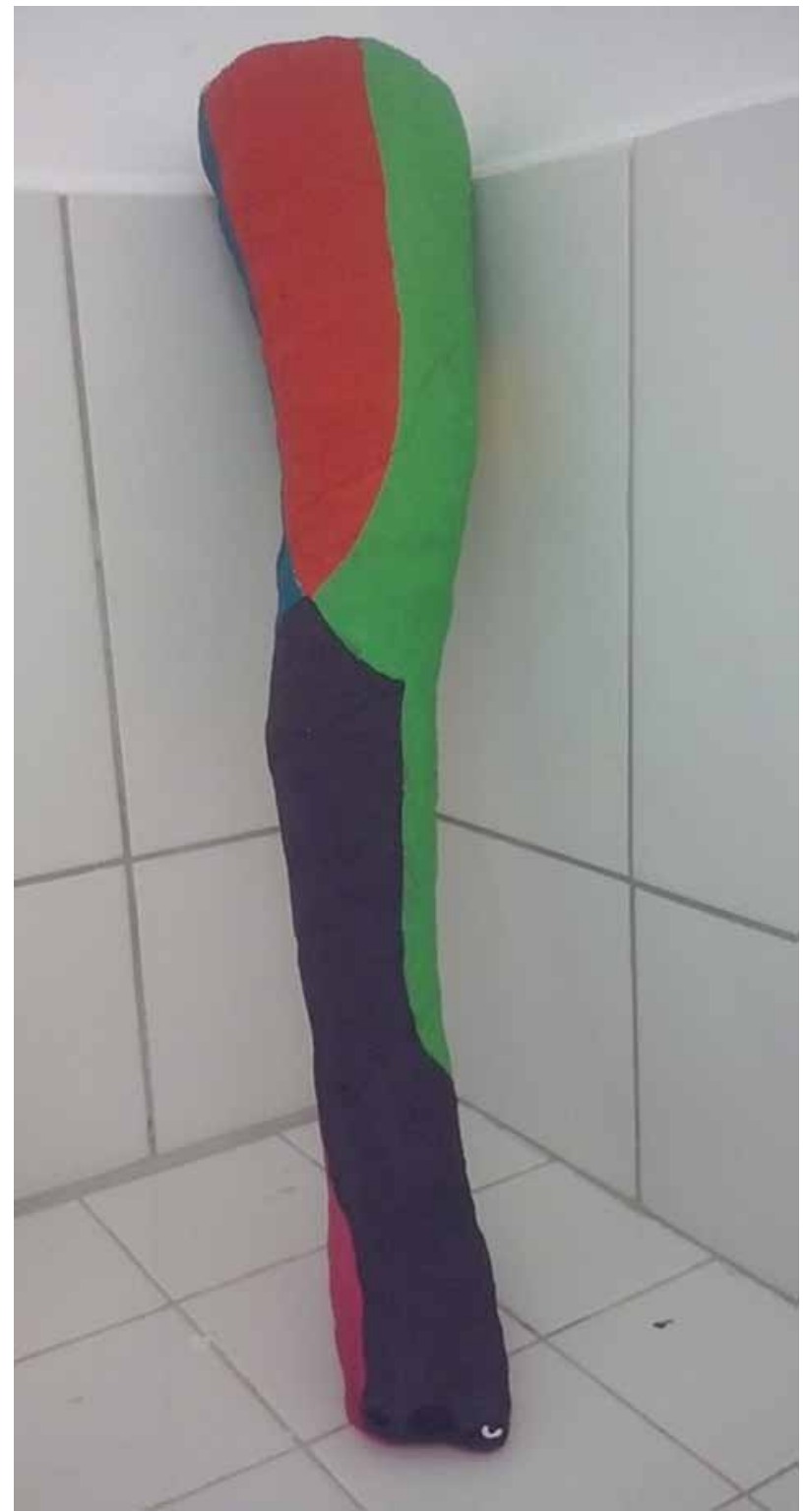

Figure 5. Lower limb dermatome. Source: elaborated by the authors. 
The scripts of the practical classes is another important resource for student learning. These possess summaries of the contents, comprising topics which will be seen in the practical class, with a simple method in developing alternatives to teaching and learning of Human Anatomy and Neuroanatomy disciplines (SILVA JÚNIOR, MORAES, DIAS et al., 2014a). It was observed that the drawing up of scripts and the manufacture anatomical models facilitate and enable the teaching and learning being important educational alternative means aimed at the new forms of teaching on the difficulties encountered in the discipline, as could be corroborated with the elaboration of this study.

\section{Conclusion}

The manufacture of neuroanatomic models appears significantly to the teaching and learning students in the discipline of Neuroanatomy, being a strong instrument for the development of practical classes for the practicability in drawing up parts and the facility in learning, for the students and for the monitors. Thus, it could be concluded that it is possible to prepare anatomical parts, as a way to minimize the problems by the lack of corpse parts, and above all with low-cost materials becoming accessible and reliable with the natural anatomical structures and the anatomic structures presented in the various atlas of Human Anatomy. But regardless of the alternatives utilized, the confection of models will never replace the use of corpse parts in the teaching of Human Anatomy.

Acknowledgements: The authors would like to acknowledge to the Academic Enhancement Program at the University of Pernambuco - PFAUPE for the financial support for the research and researchers dedication and all the staff LABEPAH (Study and Research Laboratory in Human Anatomy).

\section{References}

AVERSI-FERREIRA, TA., MONTEIRO, CA., MAIA, FA., GUIMARÃES, APRC. and CRUZ, MR. Estudo de neurofisiologia associado com modelos tridimensionais construídos durante o aprendizado. Bioscience Journal, 2008, vol. 24, n. 1, p. 98-103.

BRASIL. Lei Federal no 8.501 de 30 de novembro de 1992. Dispõe sobre a utilização de cadáver não reclamado, para fins de estudo ou pesquisas cientificas e dá outras providências. Diário Oficial da República Federativa do Brasil. Brasília, 1 dez. 1992; p. 16519.

CABELLO, CAS. A contribuição e socialização dos conhecimentos da neuroanatomia no contexto da sala de aula, no processo de ensino e aprendizagem. Revista Íbero-americana de Educação, 2009, vol. 1, n. 51, p. 1-6.

CAMpos, LML., BORTOloto, TM. and Felicio, AKC. $A$ produção de jogos didáticos para o ensino de ciências e biologia: uma proposta para favorecer a aprendizagem. Rio Claro: Instituto de Biociências da Unesp, 2002.

COLLIPAL, LE. and SILVA, MH. Estudio de la Anatomía en cadáver y modelos anatómicos: impresión de los estudiantes. International Journal Morphological, 2011, vol. 4, n. 29, p. 1181-1185.

COSTA, GBF. and LINS, CCSA. O cadáver no ensino da anatomia humana: uma visão metodológica e bioética. Revista Brasileira de Educação Médica, 2012, vol. 3, n. 36, p. 369-373.

FATTINI, CA. and DANGELO, JG. Anatomia humana sistêmicae segmentar. 3rd ed. Rio de Janeiro: Atheneu, 2011.

FORNAZIEIRO, CC., GORDAN, PA., CARVALHO, MAV., ARAUJO, JC. and AQUINO, JCB. O Ensino da Anatomia: Integração do Corpo Humano e Meio Ambiente. Revista Brasileira de Educação Médica, 2010, vol. 2, n. 34, p. 290-297.

GILrOY, AM., MACPHERSON, BR. and ROSS, LM. Atlas de Anatomia. Rio de Janeiro: Guanabara Koogan, 2008.

GRAY, H. and GOSS, CM. Anatomia. 29th ed. Rio de Janeiro: Guanabara Koogan, 2012.

JAFFAR, AA. Exploring the use of a facebook page in anatomy education. Anatomical Sciences Education, 2013, vol. 7, n. 3, p. 199-208.

JAFFAR, AA. YouTube: an emerging tool in anatomy education. Anatomical Sciences Education, 2012, vol. 5, n. 3, p. 158-164.

LIMA E SILVA, MS., MACHADO, HA., BIAZUSSI, HM. Produção de material didático alternativo para aula prática de anatomia humana. In Anais do $7^{\circ}$ Congresso Norte-Nordeste de Pesquisa e InovaçãoCONNEPI, 2012. Tocantins: IFTO, 2012. p. 1-7.

LÓPEZ, FB., SANDOVAL, MC., GIMÉNEZ, MA. and ROSALES, VP. Valoración de la actividad de modelos anatómicos en el desarrollo de competencias en alumnos universitarios y su relación con estilos de aprendizaje, carrera y sexo. International Journal Morphological, 2011, vol. 2, n. 29 , p. 568-574.

MACHADO, A. Neuroanatomia funcional. 3rd ed. Rio de Janeiro: Atheneu, 2014.

MARTIN, JH. Neuroanatomia: texto e atlas. 4th ed. Porto Alegre: AMGH, 2013.

MARTINEZ, AMB., ALLODI, S. and UZIEL, D. Neuroanatomia essencial. Rio de Janeiro: Guanabara Koogan, 2014.

MELO, EN. and PINHEIRO, JT. Procedimentos legais e protocolos para utilização de cadáveres no ensino de anatomia em Pernambuco. Revista Brasileira de Educação Médica, 2010, vol. 34, n. 2, p. 315-323.

NOBESCHI, L. Introdução ao estudo da anatomia humana. São Paulo: Instituto de Imagens em Saúde, 2010. Available from: <http://www. imagingonline.com.br/biblioteca/Leandro_Nobeschi/introducaoao-estudo-da-anatomia-humana.pdf>. Access in: 04 de May 2015.

PEREIRA, PL., CAVALCANTI, JMWMU., PORTELA, VAB., SOUZA, CI., COELHO, MCOC. and TENÓRIO, APM. Utilização de peças anatômicas como método alternativo ao modelo vivo no ensino da disciplina de anestesiologia. In Anais da $13^{a}$ Jornada de Ensino, Pesquisa e Extensão, 2013. Pernambuco: UFRPE, 2013. p. 1-2.

SILVA JÚNIOR, EX., MORAES, GNB., DIAS, TG., RIBEIRO, LP. and SCHWINGEL, PA. Elaboração de roteiros para o ensinoaprendizagem nas aulas práticas das disciplinas de anatomia humana e neuroanatomia. In Anais do $1^{\circ} C O N E D U, 2014$. Paraíba: Realize, 2014a. p. 1-5.

SILVA JÚNIOR, EX., NASCIMENTO, IYN., DIAS, TG. and SCHWINGEL, PA. Elaboração de modelos anatômicos alternativos para o ensino-aprendizagem da disciplina de neuroanatomia humana, a partir de material de baixo custo. In Anais do $1^{\circ}$ CONEDU, 2014. Paraíba: Realize, 2014b. p. 1-5.

SOBOTTA, J., PUTZ, R. and PABST, RD. Sobotta: atlas de anatomia bumana. 23th ed. Rio de Janeiro: Guanabara Koogan, 2013. 3 vols.

SOUZA JÚNIOR, I., CARVALHO, DOR., SALGADO, RDC. and SÁ, CM. Métodos de ensino-aprendizagem em anatomia humana: primeira etapa do programa institucional de bolsas acadêmicas (PIBAC) do IFPI/Campus Floriano. In Anais do $5^{\circ}$ CONNEPI, 2010. Maceió, 2010. p. 1-5. 